\title{
SIGNIFIKANSI MAQAMAT DAN AMALAN PADA PENDIDIKAN TASAWUF DALAM PERUBAHAN TINGKAH LAKU MANUSIA
}

\author{
Mihmidaty \\ (Dosen DPK UIN Sunan Ampel di FAI Universitas Sunan Giri \\ Surabaya)
}

\begin{abstract}
Abstrak:
Masyarakat dewasa ini cenderung mengikuti gaya hidup materialistic hedonistic. Pada umumnya kontak antar manusia atas dasar prinsip-prinsip fungsional, pragmatis, materialis. Manusia yang seperti itu ternyata tidak bahagia dan diliputi kegelisahan, sehingga terjadi kekeringan spiritual. Oleh karena itu sebagian manusia kembali kepada nilai-nilai keagamaan, cenderung ke arah spiritualisme. Pendidikan tasawuf merupakan alternatif untuk mengatasi masalah ini. Pendidiknya adalah seorang guru yang ma'rifat (mengenal rahasia Ketuhanan) yang diberi kemampuan oleh Allah SWT untuk membimbing jiwa menuju pada kedekatan dengan Allah SWT dan mencapai kebahagiaan yang hakiki, melalui ajaran maqamat dan amalan-amalan tertentu secara disiplin, sehingga dapat menimbulkan perubahan tingkah laku.
\end{abstract}

Kata Kunci: Maqamat, Amalan, Pendidikan Tasawuf dan Tingkah Laku

\section{A. Pendahuluan}

Allah menciptakan jiwa manusia dilengkapi dengan sifat fujur (penentangan/durhaka/kefasikan) dan ketaqwaan, sebagaimana firman-Nya: 

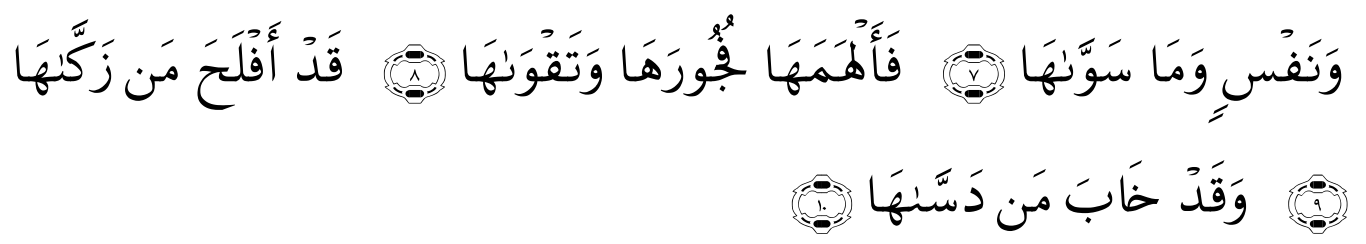

"Dan jiwa serta penyempurnaannya (penciptaannya), Maka Allah mengilhamkan kepada jiwa itu (jalan) kefasikan dan ketakwaannya. Sesungguhnya beruntunglah orang yang mensucikan jiwa itu, dan sesungguhnya merugilah orang yang mengotorinya."

Dalam ayat ini, Allah SWT menyebutkan kata fujur lebih dahulu daripada kata taqwa, hal ini memberikan sinyal kepada manusia bahwa jiwa manusia itu yang asal adalah durhaka/ fasik, oleh karena itu perlu dididik, diajar dan dilatih supaya bisa mencapai pada ketaqwaan. Pada ayat berikutnya Allah memberi pelajaran, sungguh berbahagialah orang yang mensucikan jiwa itu dan sungguh merugilah orang yang mengotorinya.

Bukan sesuatu yang mudah untuk mengubah dari jiwa yang durhaka menjadi jiwa yang taqwa, dari jiwa yang kotor menjadi jiwa yang suci. Salah satu solusinya adalah melalui pendidikan tasawuf dengan materi-materi pendidikan tasawuf yang sangat berharga. Materi pendidikan tasawuf tersebut adalah berupa maqamat atau tahapan-tahapan tertentu dan amalan-amalan yang harus dilaksanakan dalam kehidupan sehari-hari.

\section{B. Maqamat}

Maqamat adalah tingkatan-tingkatan atau tahapantahapan jalan pendakian yang harus dilalui oleh seorang murid

${ }^{1} \mathrm{Al}-\mathrm{Qur}$ 'an, 91 (al-Shams): 7-10. 
untuk mengikuti pendidikan tasawuf yang harus diusahakan secara sungguh-sungguh dalam perjalanan hidupnya. Tingkatan-tingkatan dalam maqamat ini banyak macamnya, para sufi berbeda pendapat tentang jumlahnya, ada yang membedakan antara maqamat dengan ahwal (kondisi jiwa sufi sebagai anugrah dari Allah SWT tidak melalui usaha yang sungguh-sungguh), ada pula yang tidak membedakannya, misalnya, dalam kitab Risalah al-Qusyairiyyah terdapat empat puluh sembilan maqamat, tanpa membedakannya dengan ahwal $^{2}$ tersebut.

Amalan atau perbuatan maqamat ini kalau disederhanakan antara lain berupa:

\section{Taubat}

Taubat adalah awal tempat pendakian dan maqam pertama bagi murid. Hakikat taubat menurut arti bahasa adalah "kembali", kata taba berarti kembali, maka tawbah maknanya juga kembali, artinya kembali dari sesuatu yang dicela dalam syari'at menuju sesuatu yang dipuji dalam syari'at. Allah SWT berfirman:

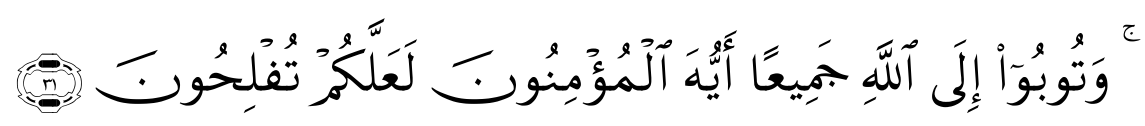

"Dan bertaubatlah kamu sekalian kepada Allah, Hai orangorang yang beriman supaya kamu beruntung."3

Rasulullah SAW. bersabda:

$$
\text { التائب من الذنب كمن لا ذ نب واذا احب الله عبدا لم يضره ذنب }
$$

${ }^{2} \mathrm{Abu}$ al-Qasim 'Abd al- Karim al Qushairy, Risalah al-Qushairiyah (Kairo: Dar alKhair, tt), 115.

${ }^{3}$ Al-Qur'an, 24 (al-Nur): 31. 
"Seorang yang bertaubat dari dosa sama dengan orang yang tidak punya dosa, dan jika Allah mencintai seorang hamba, pasti dosa tidak akan membahayakannya."4

Sesuai dengan firman Allah SWT:

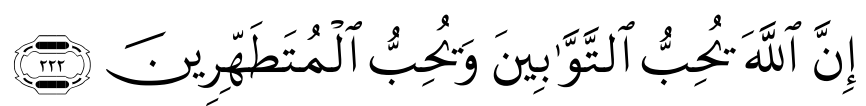

"Sesungguhnya Allah menyukai orang-orang yang bertaubat dan menyukai orang-orang yang mensucikan diri."5

Orang yang bertaubat harus memenuhi syarat: alnadm, al-iqla', al-istighfar, al-ta'abbud. ${ }^{6}$ Pertama, al-nadm berarti penyesalan dari perbuatan-perbuatan dosa, kedua, al-iqla' maksudnya menanggalkan perbuatan-perbuatan dosa seraya berjanji kepada Allah tidak akan mengulangi perbuatan dosanya, ketiga, al-istighfar adalah permohonan ampun yang sungguh-sungguh kepada Allah SWT atas segala dosanya dan yang keempat, al-ta'abbud yaitu rajin melakukan ibadah atau penghambaan diri kepada Allah SWT selama hidupnya.

Demikianlah syarat taubat yang dilakukan oleh seseorang pada umumnya, yaitu karena membersihkan diri dari kesalahan dan dosa. Namun bagi orang-orang tertentu yang terpilih (khas), taubat mereka bukan karena melakukan dosa atau kejahatan, tetapi taubat mereka adalah karena lupa atau lalai (ghaflah) dari mengingat kepada Allah SWT.7 Orang yang telah menempati maqam tinggi seperti ini, ia selalu mengingat dan dzikir kepada Allah SWT dalam

${ }^{4}$ Al-Jami' al-Shaghir Juz I, 3385

${ }^{5}$ Al-Qur'an, 2 (al-Baqarah): 222.

6 'Abd al-Wahab al-Sha'rani, Minah al-Saniyyah (Surabaya: al-Hidayah, tt.), 2.

7 Ibn 'Athaillah, Miftah al-Falah wa Mishbah al-Arwah (Mesir: Maktabah 'Ali Shabih wa Awladih, tt.), 27. 
setiap keadaan. Apabila ia melupakan-Nya dalam waktu sebentar saja, ia merasa telah melakukan dosa dan memohon ampun kepada-Nya karena kelalaiannya dalam berdzikir kepada Allah SWT.

\section{Istiqamah}

Istiqamah berarti kebenaran atau ketulusan ${ }^{8}$ dalam melaksanakan pengabdian diri kepada Allah SWT, secara terus menerus tanpa menghitung-hitung berapa banyak ia telah melakukan kabaikan. Sebagaimana sabda Nabi SAW:

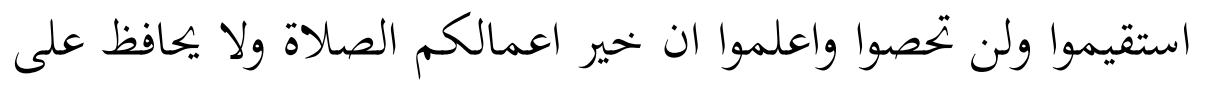

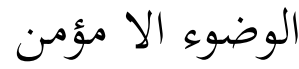

"Istiqamahlah kamu dan jangan sekali-kali menghitunghitung (amal)mu. Ketahuilah bahwa sebaik-baik (amalan) agamamu adalah shalat, dan tidak ada yang mampu menjaga wudlu selain orang mukmin." 9

Dengan demikian, istiqamah berarti teguh pendirian dalam bersikap. Sedangkan dalam beribadah adalah konsisten dan terus menerus dalam pengamalannya.

Istiqamah merupakan syarat utama bagi pemula dalam menjalani perjalanan pendidikan tasawuf. Statusnya masuk kalkulasi hukum-hukum dasar perjalanan awal shufi. Diantara tanda-tanda istiqamah bagi shufi pemula adalah ketiadaan perubahan pelaksanaan ibadahnya, meskipun hanya sekejap. ${ }^{10}$ Orang yang tidak bisa istiqamah dalam ibadahnya, maka usahanya menjadi sirna dan perjuangannya dihitung gagal. Hanya orang-orang yang

${ }^{8}$ Muhammad Idris, Kamus Idri sal-Marbawi Jilid II, 164.

${ }^{9}$ Imam Ibnu Majah,Sunan Ibnu Majah, Juz I ( Beirut: Dar al-Fakr, 2004), 103.

10 Abu al-Qasim, Risalah, 294. 
berjiwa besar saja yang dapat menjalankan istiqamah ini. Allah SWT juga memerintahkan istiqamah dengan firmanNya:

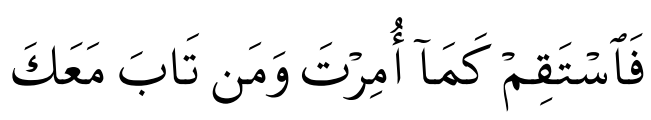

"Maka tetaplah kamu (istiqamah) pada jalan yang benar, sebagaimana diperintahkan kepadamu dan (juga) orang yang telah taubat beserta kamu."11

Allah SWT akan menganugerahkan kebaikan kepada orang yang dapat melaksanakan istiqamah ini, dengan firmanNya:

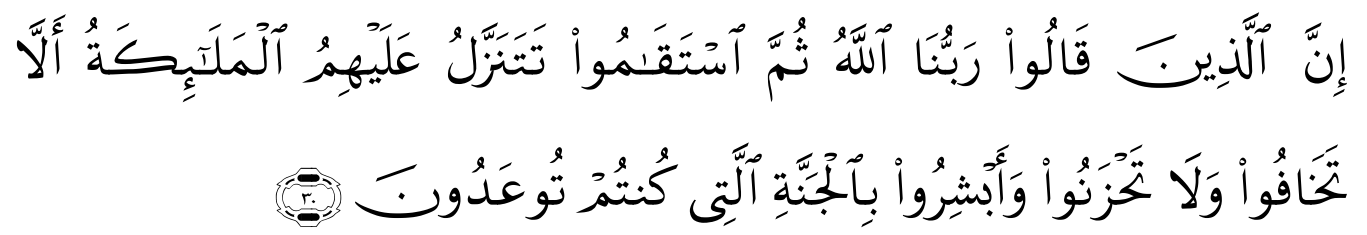

"Sesungguhnya orang-orang yang mengatakan: 'Tuhan Kami ialah Allah' kemudian mereka meneguhkan pendirian mereka, Maka Malaikat akan turun kepada mereka dengan mengatakan: Janganlah kamu takut dan janganlah merasa sedih; dan gembirakanlah mereka dengan jannah (surga) yang telah dijanjikan Allah kepadamu".12

Demikianlah penjelasan Allah SWT bahwa orang yang dapat melaksanakan istiqamah dalam pengabdian diri kepada-Nya, maka Allah SWT menjamin tidak akan ada ketakutan dan kesedihan dalam hidupnya dan Allah SWT menjanjikan kebahagiaan di surga kelak di akhirat.

${ }^{11}$ Al-Qur'an, 11 (Hud): 112.

${ }^{12} \mathrm{Al}$-Qur'an, 41 (Fushshilat): 30. 
Dan firman-Nya:

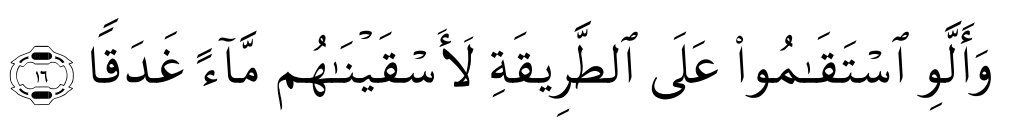

"Dan bahwasanya: Jikalau mereka tetap berjalan lurus (istiqamah) di atas jalan itu (agama Islam), benar-benar Kami akan memberi minum kepada mereka air yang segar (rezki yang banyak)."13

Dalam ayat tersebut, Allah SWT memotivasi pada manusia agar menerapkan istiqamah dalam hidupnya. Hal ini telah dilaksanakan dalam pendidikan tasawuf. Murid yang telah menerapkan istiqamah ini, memiliki empat tanda/ciri pada dirinya, yaitu: 1). Kalau diberi kebaikan oleh seseorang, tidak mendorongnya untuk berbuat baik pada orang yang memberi. 2). Kalau dijeleki oleh seseorang, tidak mendorongnya untuk berbuat jelek kepadanya. 3). Hawa nafsunya tidak memalingkan ketaatannya kepada Allah SWT. 4). Harta benda tidak menyurutkan hatinya dalam taat kepada Allah SWT. ${ }^{14}$

Hal tersebut terjadi karena dia berkeyakinan bahwa kebaikan hanya datang dari Allah SWT saja, demikian juga kejelekan, hawa nafsu dan harta benda yang diberikan oleh Allah SWT kepada manusia, untuk menguji, yang disikapinya dengan sabar dan syukur.

\section{Zuhud}

Ibnu 'Ujaibah mendefinisikan zuhud dengan perkataannya, "Zuhud adalah kosongnya hati dari ketergantungan kepada selain Allah SWT." Zuhud berarti

\footnotetext{
${ }^{13}$ Al-Qur'an, 72 (al-Jin):16.

14 Shaykh Mas'ud Thaha, Murshid Thariqah Shahaliyah dan Pengasuh Pondok Pesantren Nurul Huda Magelang, Ceramah, Magelang, 16 November 1999.
} 
mengosongkan hati dari cinta kepada dunia dan semua keindahannya, dan mengisinya dengan cinta kepada Allah SWT serta ma'rifat kepada-Nya. ${ }^{15}$ Kalau hati manusia terlepas dari ketergantungan pada dunia dan kesibukannya, maka akan menambah cintanya kepada Allah SWT, berserah diri dan menghadapkan perhatian kepada Allah SWT.

Al-Sarraj menegaskan bahwa zuhud adalah maqam yang mulia, dan ini merupakan langkah awal bagi seseorang yang menuju Allah SWT. ${ }^{16}$ Perumpamaan antara dunia dengan akhirat adalah seperti seorang nenek tua keriput yang penuh penyakit dan seorang gadis muda yang cantik. ${ }^{17}$ Jika seorang pemuda mau menikah tentu memilih seorang gadis muda yang cantik. Seorang mu'min tentu memilih kehidupan akhirat yang diibaratkan gadis cantik itu. Jadi zuhud adalah keinginan hati untuk tidak menginginkan segala kepentingan dunia.

Oleh karenanya, dalam al-Qur'an banyak ayat yang memandang rendah urusan dunia, menjelaskan kehinaannya dan kenikmatannya yang mudah hilang serta menekankan bahwa dunia tempat tipu daya, kebohongan dan fitnah bagi orang-orang yang lalai. Hal ini dimaksudkan agar manusia zuhud terhadap dunia dengan menghilangkan kecintaan dunia dalam hati mereka, sehingga dunia tidak menyibukkan mereka dari tujuan penciptaan manusia yang sebenarnya yaitu mengabdi dan menghamba kepada Allah SWT saja.

\footnotetext{
15 'Abdul Qadir 'Isa, Hakikat Tasawuf ( Jakarta: Qisthi Press, 2005), 248.

${ }^{16}$ Al-Sarraj, al-Luma' fi al-Tashawwuf (Kairo: Dar al-Kutub al-Hadithah,1960), 72.

17 'Ali Hasan al-'Aridh, Bahjat al-Nufus li Ibn 'Athaillah (Kairo: M.Taufiq Uwaudhat,1969), 162.
} 
Firman Allah SWT tersebut antara lain adalah:

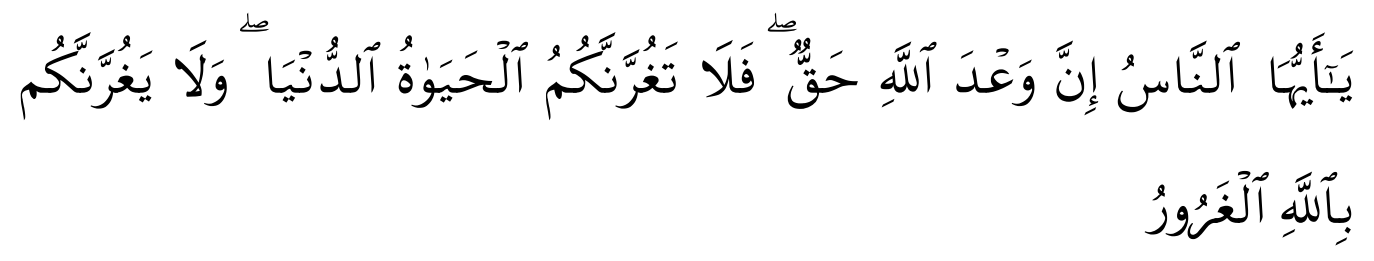

"Hai manusia, Sesungguhnya janji Allah adalah benar, maka sekali-kali janganlah kehidupan dunia memperdayakan kamu dan sekali-kali janganlah syaitan yang pandai menipu, memperdayakan kamu tentang Allah." 18

Dan firman Allah SWT:

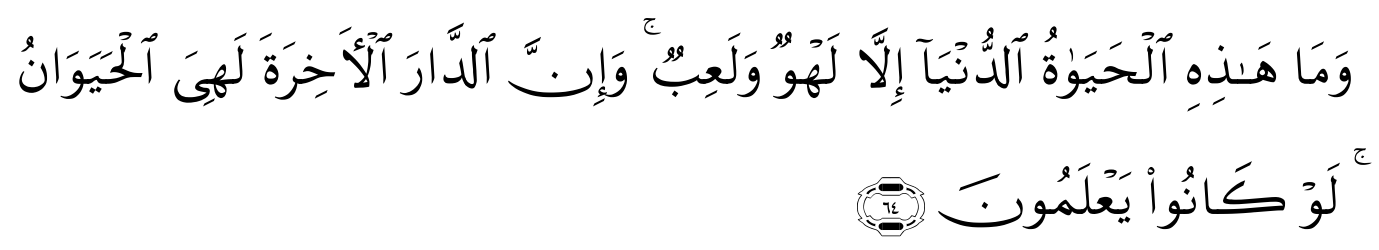

"Dan Tiadalah kehidupan dunia ini melainkan senda gurau dan main-main. dan Sesungguhnya akhirat Itulah yang sebenarnya kehidupan, kalau mereka mengetahui."19

Serta firman Allah SWT:

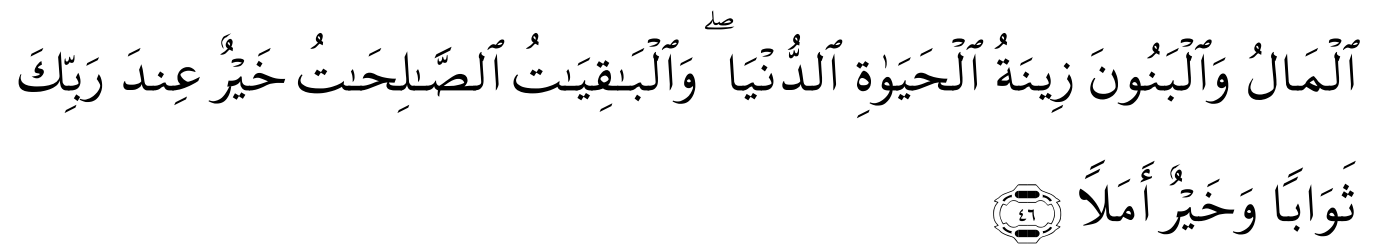

"Harta dan anak-anak adalah perhiasan kehidupan dunia tetapi amalan-amalan yang kekal lagi saleh adalah lebih baik pahalanya di sisi Tuhanmu serta lebih baik untuk menjadi harapan."20

${ }^{18}$ Al-Qur'an, 35 (al-Fathir): 5.

${ }^{19}$ Al-Qur'an, 29 (al-Ankabut): 64.

20 Al-Qur'an, 18 (al-Kahfi): 46.

Jurnal Pendidikan Agama Islam Volume 02 Nomor 01 Mei 2014

Hal $60-87$ 
Allah SWT juga berfirman:

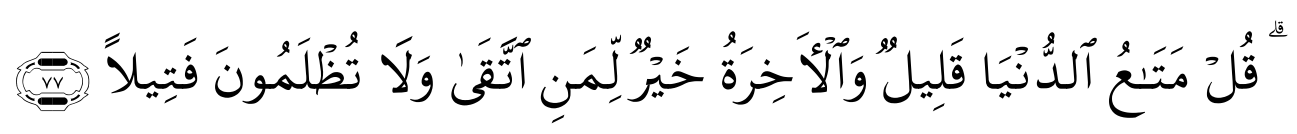

"Katakanlah: "Kesenangan di dunia ini hanya sebentar dan akhirat itu lebih baik untuk orang-orang yang bertakwa, dan kamu tidak akan dianiaya sedikitpun."21

Demikian Allah SWT memberi pelajaran kepada manusia agar hati-hati tentang urusan dunia dan mengutamakan semua urusan yang berhubungan dengan Allah SWT untuk persiapan mencapai kebahagiaan dalam kehidupan yang sebenarnya yaitu kehidupan di akhirat. Hal ini telah diejawantahkan oleh Rasulullah SAW. sebagai uswah hasanah (contoh teladan yang baik) bagi ummatnya. Sebagaimana yang diillustrasikan oleh 'Urwah dari 'Aisyah:

$$
\begin{aligned}
& \text { عن عروة عن عائسة رضي الله عنها اها كانت نقول: والله يا ابن اختى ان } \\
& \text { كنا لنظظر الى الهلال ثم الهلال ثم الهلال ثلاثة اهلة في شهرين. وما اوقد في } \\
& \text { ابيات رسول الله صل الله عليه وسلم نار قال: قلت يا خالة ! فما كان }
\end{aligned}
$$

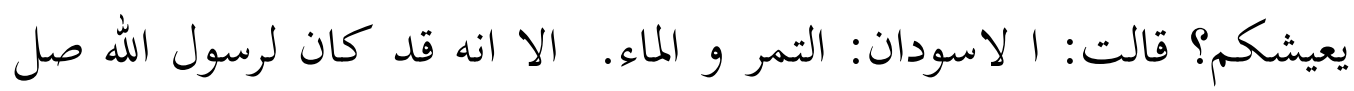

$$
\begin{aligned}
& \text { الله عليه وسلم جيران من الانصار. وكانت لهم منائح فكانوا يرسلون الى رسول } \\
& \text { الله صل الله عليه وسلم من الباها فيسقينا هـ }
\end{aligned}
$$

"Diriwayatkan dari 'urwah dari 'Aisyah r.a. dia berkata"Demi Allah, hai kemenakanku, kami pernah menghitung awal tanggal sampai awal tanggal berikutnya, sampai tanggal berikutnya lagi yaitu tiga kali awal tanggal selama dua bulan tidak ada sesuatu yang dimasak di dapur Rasulullah SAW. 'Urwah bertanya, 'Hai bibi, lalu kalian semua makan apa?'

${ }^{21}$ Al-Qur'an, 4 (al-Nisa'): 77. 
'Aisyah r.a. menjawab, 'Kurma dan air'. Hanya Rasulullah SAW. Bertetangga dengan orang-orang Anshar dan mereka mendapat banyak rizki, sehingga mereka sering mengirimkan sebagian air susu hewan mereka kepada Rasulullah SAW., lalu; kami menghidangkannya kepada beliau."22

Rasulullah SAW. juga memberikan pengertian yang benar tentang zuhud dengan sabdanya:

الزهادة في الدنيا ليست بتحريم الحلال ولا اضاعة المال ولكن الزهادة فن الدنيا

ان لا تكون بما في يديك اوثق مما فن يدي الله وان تكون في ثواب المصيبة اذا انت اصبت بها ارغب فيها لو انها ابقيت لك لك لكوان

"Zuhud terhadap dunia bukanlah mengharamkan yang halal dan menyia-nyiakan harta, akan tetapi, zuhud terhadap dunia adalah engkau lebih percaya pada apa-apa yang ada di sisi Allah daripada apa-apa yang ada di tanganmu, dan pahala musibah yang menimpamu membuatmu lebih suka seandainya ia terus menimpamu."23

Dari hadith tersebut, dapat dimengerti bahwa zuhud adalah kondisi hati, bukan berarti melepaskan diri dari halhal duniawi, sehingga mengosongkan tangannya dari harta, meninggalkan usaha halal dan menjadi beban bagi orang lain. Tetapi hatinya tetap dihadapkan kepada Allah SWT dengan memanfaatkan dunia untuk mencapai kebahagiaan akhirat, karena akhirat tidak akan didapat kecuali dengannya. Ayat-ayat al-Qur'an dan hadith-hadith tersebut bukanlah celaan pada dunia itu sendiri, tetapi maksudnya adalah peringatan agar hati manusia tidak sibuk dengannya,

22 Imam Bukhari, Shahih Bukhari, Juz II (Beirut: Dar al-Kutub al-'Ilmiyah, 2005), 165. Lihat juga Imam Muslim, Shahih Muslim, Juz II, 589.

${ }^{23}$ Imam Tirmidhi, Sunan al-Tirmidhi (Beirut: Dar Ibnu Hazm, 2002), 673-674, 
dengan menjadikannya sebagai tujuan dan berusaha sekuat mungkin untuk memperolehnya, serta melupakan tujuan hidup yang utama, yaitu meraih ridha Allah SWT.

Cara untuk mencapai zuhud antara lain yang paling penting adalah bergaul atau berguru pada murshid yang dapat menunjukkannya pada jalan yang benar, membawanya dari tingkatan yang satu ke tingkatan yang lain dengan cara yang bijaksana dan menjauhkannya dari hal-hal yang dapat menjerumuskan. ${ }^{24}$

Dalam hal ini, seorang murshid kadang menugaskan bentuk mujahadah tertentu kepada murid-muridnya agar mereka dapat mengosongkan hati mereka dari ketergantungan terhadap dunia. Dia memerintahkan pada mereka agar memakan makanan yang sedikit dan memakai pakaian yang sederhana, untuk menghilangkan kecintaan terhadap dunia dari hati mereka; atau dia mengajak mereka berderma dengan jumlah yang besar untuk kepentingan agama Allah SWT agar dapat melepaskan sifat-sifat kikir dan kecintaan terhadap harta benda dari hati mereka. Hal ini hanyalah sarana yang di-shari'at-kan untuk mencapai zuhud hati yang hakiki, yang merupakan sebab untuk sampai kepada Allah SWT, karena hati tidak akan sampai kepadaNya apabila masih bergantung pada sesuatu selain Allah SWT.

\section{Raja'}

Raja' adalah kepercayaan dan pengharapan atas ridha dan karunia Allah SWT yang dibuktikan dengan amal. ${ }^{25}$ Ada yang berpendapat bahwa raja' merupakan sikap percaya terhadap kedermawanan Allah SWT. Pendapat lain

24 'Abdul Qadir, Hakikat, 256.

${ }^{25} \mathrm{Abu}$ 'Abbas Ahmad Zaruq al-Fasi, Qawa'id al-Tashawwuf, 74. 
mengatakan raja' adalah senangnya hati terhadap tempat kembali yang baik (akhirat). Ada pula yang berpendapat raja' adalah dekatnya hati terhadap kelemah-lembutan Tuhan. ${ }^{26}$ Hal ini diperintahkan oleh Allah SWT pada manusia agar mengharapkan karunia-Nya dan melarang berputus asa dari rahmat-Nya. Sebagaimana firman Allah SWT:

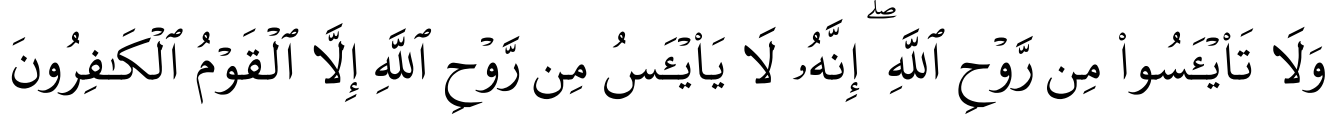
"Dan jangan kamu berputus asa dari rahmat Allah. Sesungguhnya tiada berputus asa dari rahmat Allah, melainkan kaum yang kafir."27

Allah SWT menyifati orang yang selalu mengharap rahmat-Nya dalam firman-Nya:

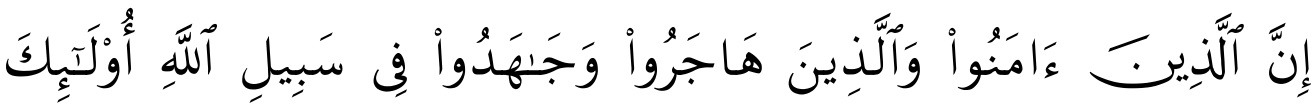

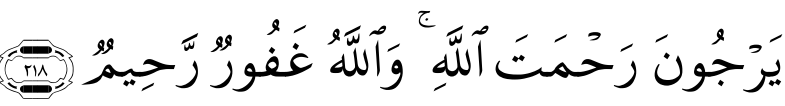

"Sesungguhnya orang-orang yang beriman, orang-orang yang berhijrah dan berjihad di jalan Allah, mereka itu mengharapkan rahmat Allah, dan Allah Maha Pengampun lagi Maha Penyayang."28

Dan firman Allah SWT:

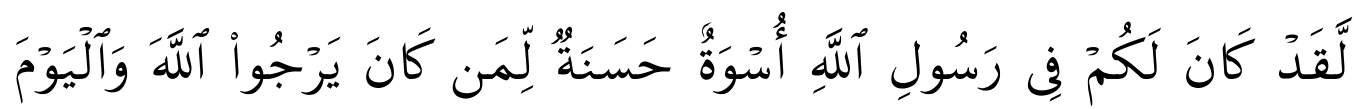

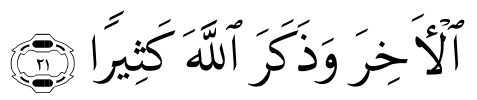

"Sesungguhnya telah ada pada (diri) Rasulullah itu suri teladan yang baik bagimu (yaitu) bagi orang yang

\footnotetext{
${ }^{26}$ Abu al-Qasim, Risalah al-Qushairiyah, 179.

27 Al-Qur'an, 12 (Yusuf), 87.

${ }^{28}$ Al-Qur'an, 2 (al-Baqarah): 218. 
mengharap (rahmat) Allah dan (kedatangan) hari kiamat dan Dia banyak menyebut Allah." 29

Orang yang mengharap dan mencari rahmat Allah SWT, akan berusaha dengan sungguh-sungguh dan berijtihad dengan penuh ketulusan dan keikhlasan sampai dia memperoleh apa yang dicita-citakan. Firman Allah:

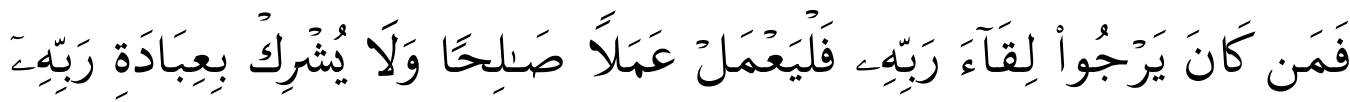
أَحَدَرا

"Barangsiapa mengharap perjumpaan dengan Tuhannya, Maka hendaklah ia mengerjakan amal yang saleh dan janganlah ia mempersekutukan seorangpun dalam beribadat kepada Tuhannya."30

Oleh karena itu, sebenarnya raja' (harapan) adalah ketergantungan hati pada sesuatu yang dicintai atau yang diinginkan yang akan terjadi pada masa yang akan datang. Sebagaimana khawf (rasa takut) yang juga berhubungan dengan sesuatu yang akan terjadi di masa yang akan datang.

Seseorang yang sedang menghadap kepada Allah dan berjalan untuk mencapai kedekatan di sisi-Nya, maka sebaiknya dia menggabungkan antara khawf dan raja. Terbang dengan kedua sayap itu (khawf dan rajả) di udara yang jernih, sehingga dapat mencapai kedekatan di hadirat Allah. Dengan demikian dapat mewujudkan sifat orangorang yang disebutkan oleh Allah SWT dalam firman-Nya:

${ }^{29}$ Al-Qur'an, 33 (al-Ahzab): 21.

30 Al-Qur'an, 18 ( al-Kahfi), 110. 

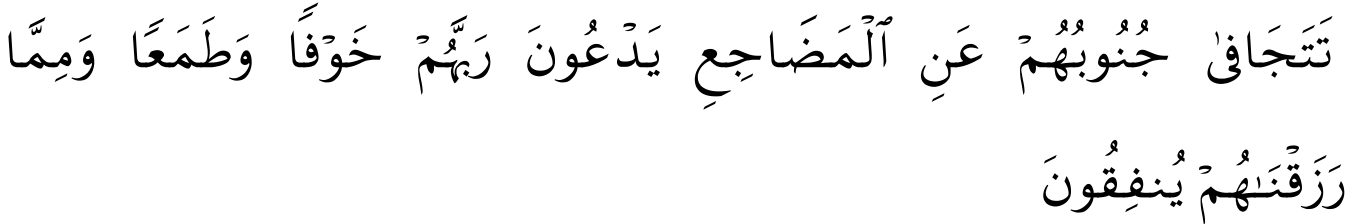

"Lambung mereka jauh dari tempat tidurnya" dan mereka selalu berdoa kepada Rabbnya dengan penuh rasa takut dan harap, serta mereka menafkahkan apa apa rezki yang Kami berikan." 32

Dalam arti takut neraka-Nya dan mengharap surgeNya, takut jauh dari-Nya dan mengharap untuk berada di dekat-Nya, takut dibenci-Nya dan mengaharap ridha-Nya, takut putus hubungan dengan-Nya dan mengharap dapat terus berinteraksi dengan-Nya.

\section{Qana'ah}

Menurut Abu 'Abdillah bin Khafif, qana'ah adalah meninggalkan angan-angan terhadap sesuatu yang tidak ada dan menganggap cukup dengan sesuatu yang ada. ${ }^{33}$ Sedangkan menurut Muhammad bin 'Ali al-Turmuzi, qana'ah adalah jiwa yang rela terhadap rizki yang telah ditentukan. Pendapat yang lain menyatakan qana'ah adalah menganggap cukup dengan sesuatu yang ada dan tidak berkeinginan terhadap sesuatu yang tidak ada hasilnya serta rela terhadap keputusan Allah SWT. ${ }^{34}$

Orang yang dapat memasukkan qana'ah dalam jiwanya, akan diberi oleh Allah SWT kehidupan yang baik di dunia, kemulyaan dan kekayaan. Allah SWT berfirman:

31 Maksudnya mereka tidak tidur di waktu biasanya orang tidur untuk mengerjakan shalat malam.

32 Al-Qur'an, 32 (al-Sajdah), 16.

${ }^{33}$ Al-Qusyairy, Risalah, 221.

34 Al-Qusyairy, 222.

Jurnal Pendidikan Agama Islam

Volume 02 Nomor 01 Mei 2014

Hal $66-87$ 


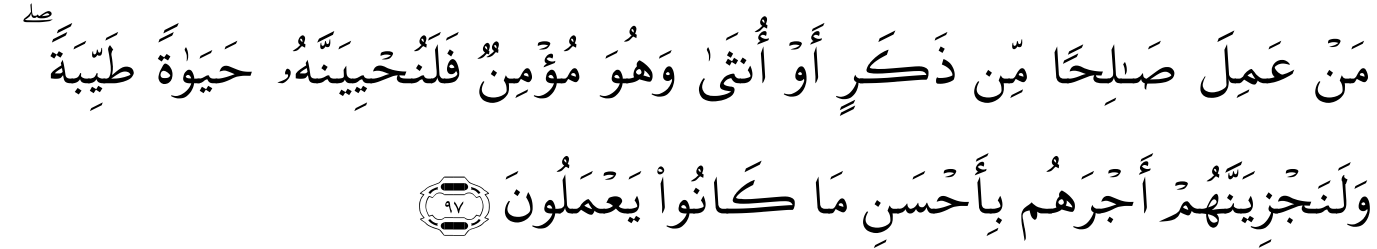

"Barangsiapa yang mengerjakan amal saleh, baik laki-laki maupun perempuan dalam Keadaan beriman, Maka Sesungguhnya akan Kami berikan kepadanya kehidupan yang baik dan Sesungguhnya akan Kami beri Balasan kepada mereka dengan pahala yang lebih baik dari apa yang telah mereka kerjakan." 35

Dan firman Allah SWT:

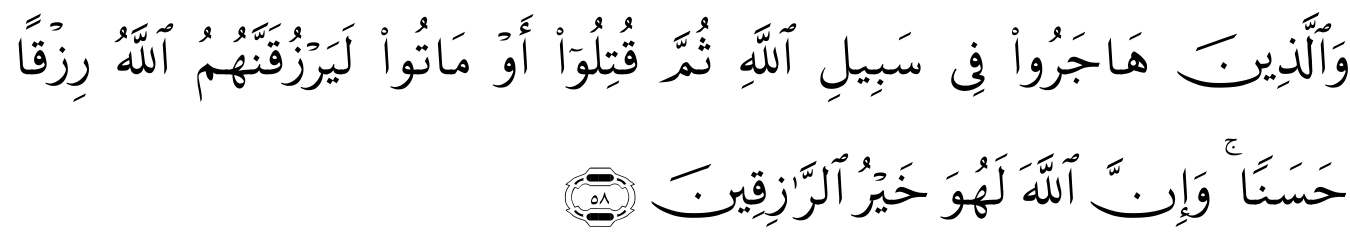

"Dan orang-orang yang berhijrah di jalan Allah, kemudian mereka di bunuh atau mati, benar-benar Allah akan memberikan kepada mereka rezki yang baik (surga). dan Sesungguhnya Allah adalah Sebaik-baik pemberi rezki." "36

Para ahli tafsir mengatakan, "Kehidupan yang baik di dunia adalah qana'ah (menerima atau merasa puas)". Dan yang dimaksud firman Allah SWT Dia akan memberikan rizki kepada mereka degan rizki yang baik adalah "qana'ah".

\section{Amalan-amalan dalam Pendidikan Tasawuf}

\section{Istighfar}

Istighfar adalah memohon ampun kepada Allah SWT dari segala dosa yang telah dilakukan oleh seseorang. Esensi

${ }^{35}$ Al-Qur'an, 16 (al-Nahl): 97.

36 Al-Qur'an, 22 (al-Hajj): 58. 
istighfar adalah taubat dan kembali kepada Allah SWT dari hal-hal yang tercela menuju hal-hal yang terpuji. Ibn 'Athaillah menyatakan bahwa seorang murid yang melangkah menuju Allah SWT, apabila sebelumnya merasa banyak melakukan dosa dan kejahatan, maka mulailah dengan banyak membaca istighfar atau meminta ampun kepada Allah SWT sampai kelihatan buahnya. ${ }^{37}$

Orang yang mengucapkan istighfar pada hakikatnya adalah mengakui dan menyesali kesalahan-kesalahan yang telah diperbuat, ia berjanji kepada Allah SWT untuk tidak mengulangi perbuatannya yang salah, baik yang tersembunyi maupun yang kelihatan. Jika janji taubat itu diucapkan karena manusia lain, maka janji itu adalah palsu karena ia tak akan berbuat kesalahan lagi jika dilihat oleh orang lain, tetapi ia akan mengulangi perbuatannya jika tidak ada seorang pun yang melihatnya. Inilah taubat orangorang awam yang disinyalir oleh Zunnun al-Mishri, yaitu taubat dari dosa-dosanya yang telah diperbuat. ${ }^{38}$

Allah SWT berfirman:

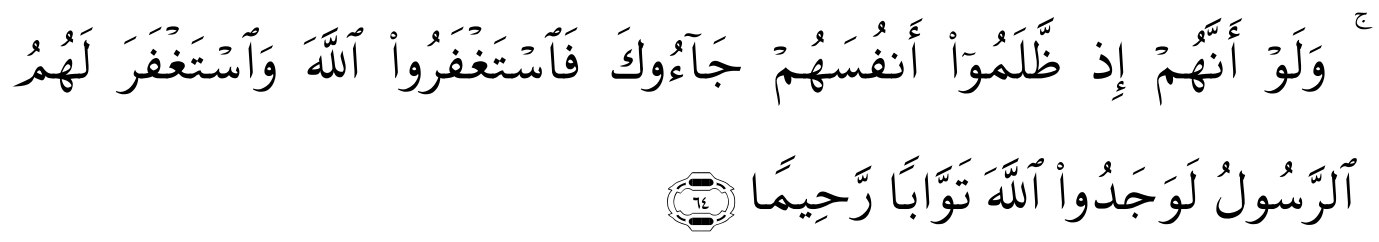

"Sesungguhnya Jikalau mereka ketika menganiaya dirinya datang kepadamu, lalu memohon ampun kepada Allah, dan Rasulpun memohonkan ampun untuk mereka, tentulah mereka mendapati Allah Maha Penerima taubat lagi Maha Penyayang."39

\footnotetext{
37 'Abdul Kadir, Hakikat, 248.

38 'Abdul Kadir, Hakikat, 248.

${ }^{39}$ Al-Qur'an, 4 (al-Nisa'), 64. 
Rasulullah SAW bersabda:

$$
\begin{aligned}
& \text { والذي نفسي بيده لو لم تذنبوا لذهب الله تعالى بكم وجاء بقوم يذنبون } \\
& \text { فيستغفرون الله تعالى فيستغفر لهم (رواه مسلم) }
\end{aligned}
$$

"Demi Dhat yang menguasai diriku, apabila kamu sekalian melakukan dosa maka Allah akan meninggalkanmu, dan ada suatu kaum yang melakukan dosa dan mereka mohon ampun kepada Allah, maka Allah pun mengampuni mereka."40

Dari ayat dan hadith tersebut di atas, dapat difahami bahwa barang siapa yang melakukan kejahatan dan dosa sedangkan mereka sanggup dengan rendah hati memohon ampun kepada Allah SWT, maka Allah SWT akan mengampuninya. Apabila seseorang telah diampuni-Nya, maka ia kembali bersih dan tiada cela dalam dirinya, kebaikan bukanlah orang yang tidak pernah berbuat dosa, tetapi orang yang berbuat dosa dan menyadari kesalahannya serta memohon ampunan-Nya.

Adapun istighfar yang diajarkan dalam pendidikan tasawuf pada umunya adalah dengan membaca astghfirulla>hal 'az\}i<m dibaca seratus kali setiap setelah sholat fardlu. Hal juga perlu tetap dilakukan oleh seorang hamba yang telah diampuni dosanya dan dirinya telah kembali bersih dengan mengganti kotoran jiwa dan hati dengan tetap istiqa>mah membaca istighfar dan mengisi jiwa dan hatinya dengan berbagai kebaikan dan amal shaleh.

\section{Dzikir}

Termasuk amalan yang utama dalam pendidikan tasawuf adalah dzikir, yaitu mengingat dan selalu menyebut

40 Sayyid Ahmad Hashimi, Mukhtar al-Hadith al-Nabawiyyah (Kairo: Shirkah Nur Asia, tt), 184. 
nama Allah SWT. Dzikir adalah ajaran pertama yang diwahyukan Allah SWT kepada Nabi Muhammad SAW melalui Malaikat Jibril ketika berkhalwat di gua hira', sebelum Allah SWT menurunkan shari'at; shalat, zakat, puasa dan haji, dengan firman-Nya:

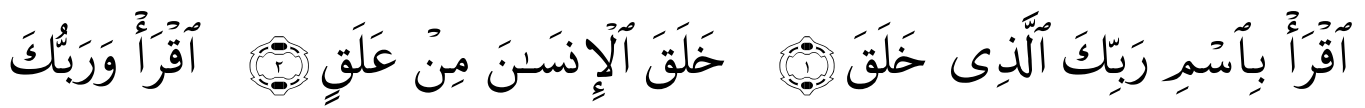

"1. Bacalah dengan (menyebut) nama Tuhanmu yang Menciptakan, 2. Dia telah menciptakan manusia dari segumpal darah. 3. Bacalah, dan Tuhanmulah yang Maha pemurah." 41

Kata "bacalah" pada ayat ini difahami sebagai dhikir, karena pada ayat tersebut dilanjutkan dengan menyebut nama Tuhanmu yang Maha menciptakan, yang telah menciptakan manusia dari segumpal darah dan Dia Maha pemurah, dan karena waktu diturunkan ayat ini belum ada al-Qur'an (belum ada yang dibaca). Allah SWT juga berfirman:

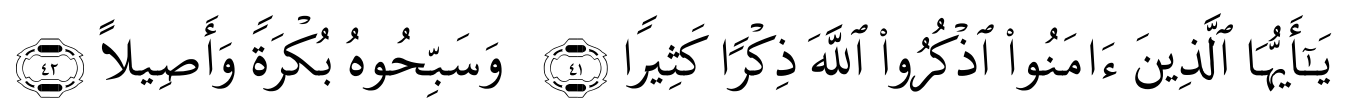

"Hai orang-orang yang beriman, berdhikirlah (dengan menyebut nama) Allah, dhikir yang sebanyak-banyaknya. Dan bertasbihlah kepada-Nya diwaktu pagi dan petang. ${ }^{42}$

Dan firman Allah SWT:

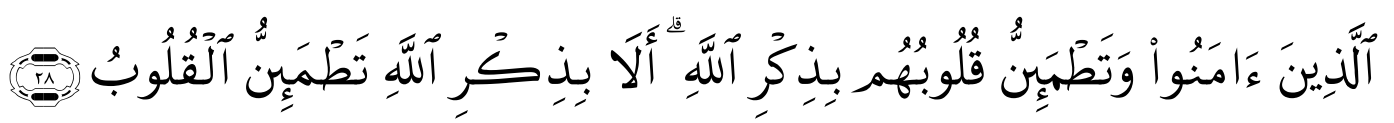

${ }^{41}$ Al-Qur'an, 96 (al-'Alaq): 1-3.

${ }^{42}$ Al-Qur'an, 33 (al-Ahzab): 41-42. 
"(yaitu) orang-orang yang beriman dan hati mereka manjadi tenteram dengan mengingat Allah. Ingatlah, hanya dengan mengingati Allah-lah hati menjadi tenteram." ${ }^{\prime 3}$

Di dalam ayat tersebut Allah SWT memerintahkan kepada orang-orang yang beriman agar berdzikir atau selalu ingat kepada Allah SWT dengan membaca dzikir yang banyak. Dalam menyebut ayat tentang dzikir, Allah SWT sering kali memerintahkan dhikir yang banyak, mengapa demikian? Tentu Dia Yang Maha Tahu. Hanya saja kalau diperhatikan secara seksama, untuk dapat menghayati, memasukkan pemahaman tentang hakikat apa yang dibaca kedalam relung hati, maka membutuhkan proses pengulangulangan secara terus menerus. Berarti dengan kuantitas dzikir akan menimbulkan kualitas dhikir itu sendiri.

Dalam ayat berikutnya Allah SWT memberi pelajaran bahwa sesungguhnya hanya dengan menyebut nama-Nya atau berdhikir kepada-Nya, hati orang yang beriman dapat merasa tentram. Hal itu karena orang yang beriman adalah orang-orang yang mencintai Allah SWT, dan orang yang mencintai-Nya akan selalu menyebut nama-Nya, maka ia merasa tentram. Hal demikian adalah rasional karena secara psikologis kerinduan orang yang mencintai akan terpenuhi dengan selalu menyebut nama yang dicintainya dengan berharap bertemu dengan-Nya. Allah SWT akan hadir pada diri orang yang selalu ingat dan menyebut nama-Nya, bahkan lebih dekat dari pada urat nadinya. Rasulullah SAW bersabda:

43 Al-Qur'an, 13 (al-Ra'd): 28. 


$$
\begin{aligned}
& \text { عن ابى هريرة رضى الله عنه ان رسول الله م قال: يقول الله تعالى انا عند } \\
& \text { ظنِ عبدى بي و انا معه اذا ذكرنى فاءن ذكرنى في نفسه ذكرته فن نفسى وان } \\
& \text { ذكرنف في ملاء ذكرته في ملاء خيرمنهم وان تقرب الى شبرا تقربت اليه ذراعا } \\
& \text { وان تقرب الى ذراعا تقربت اليه باعا وان ان اتان يمشى اتيته هرولة (رواه }
\end{aligned}
$$

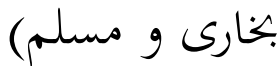

"Dari Abu Hurairah r.a. sesungguhnya Rasulullah bersabda bahwa Allah berfirman: Aku berada dalam prasangka hambaKu padaKu dan Aku menyertainya jika ia mengimgatKu, jika mengingatKu dalam dirinya maka Aku akan mengingatnya dalam diriKu dan jika mengingatKu dalam suatu kelompok (jama'ah) maka Aku akan mengingatnya dalam suatu kelompok (jama'ah) yang lebih baik dari itu, jika ia mendekatiKu sejengkal jari, maka Aku mendekatinya sepanjang siku-siku dan jika dia mendekatiKu sepanjang siku-siku, maka aku mendekatinya sepanjang hasta, dan jika dia mendatangiku dengan berjalan maka Aku mendatanginya dengan berlari." ${ }^{44}$

Hadith tersebut menegaskan bahwa Allah SWT akan menyertai atau bersama orang yang senantiasa mengingat Allah SWT dalam dirinya baik secara individu maupun secara kolektif. Berarti Allah SWT sangat dekat dengan orang-orang yang selalu berdhikir kepada-Nya bahkan Allah SWT akan mengingat dan mendekat secara lebih baik dan lebih cepat daripada apa yang telah dilakukan oleh dhakir (orang yang mengingat Allah SWT). Jika seseorang mendekati-Nya dengan berjalan, maka Allah SWT akan

\footnotetext{
44 Imam Bukhari, Shahih Bukhari, Juz IV ( Beirut: Dar al-Kutub al 'Ilmiyah, 2005), 541. Lihat juga Imam Muslim, Shahih Muslim, Juz II (Mesir: Isa al-Babi alHalibi, tt.), 466.
} 
mendekati hamba-Nya dengan berlari agar segera saling bertemu (liqa') dan saling menyatu (ittihad).

Rasulullah Muhammad SAW bersabda:

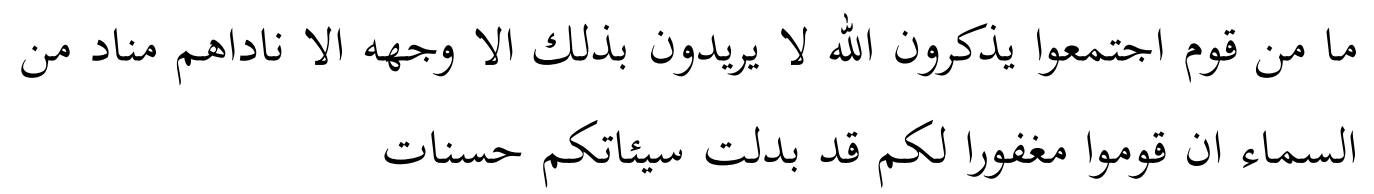

"Tidak ada segolongan manusiapun yang berkumpul dan melakukan dhikir kepada Allah dengan tidak ada niat lain selain untuk Allah semata-mata, kecuali nanti akan datang seruan dari langit:"Bangkitlah kamu semua, sudah diampuni dosa kalian dan sudah ditukar kejelekan kalian yang telah lalu dengan kebaikan."45

Dzikir yang diamalkan oleh para murid dalam pendidikan tasawuf pada umumnya adalah kalimah thayyibah atau bacaan tahlil yang juga disebut dengan dhikir nafi (meniadakan) ithbat (menetapkan) yang berbunyi lailaha illalah (tidak ada Tuhan selain Allah SWT) dengan cara dibunyikan secara perlahan dan dibaca panjang dengan mengingat maknanya yaitu tiada dzat yang dituju kecuali Allah SWT (la maqshuda illa Allah), bacaan kedua dengan mengingat maknanya yaitu tiada yang disembah selain Allah SWT (la ma'buda illa Allah) dan bacaan ketiga dengan mengingat maknanya tiada yang ada selain Allah SWT (la maujuda illa Allah), diakhiri dengan bacaan sayyiduna Muhammad Rasulullah SAW. Kemudian diteruskan dhikir nafi ithbat: la ilaha illa Allah sebanyak seratus kali setiap setelah shalat fardlu. Dan dianjurkan dalam hati senantiasa dhikir ism al-dzat (menyebut nama Allah, Allah, Allah).

45 Imam Turmudzi, Sunan Turmudzi (Beirut: Dar al-Fikr,1980), 127-128. 
Mengucapkan amalan dzikir nafi ithbat ini biasanya dilakukan dengan merasakan bahwa dzikir itu "ditarik" melalui suatu alur di badannya, dari pusar ke otak, kemudian ke dada kanan dan dari sini dengan keras "dipukulkan" ke jantung (dada kiri). Demikian juga hati dibersihkan dari segala kotoran, sehingga di dalamnya tidak tersisa selain nama Allah SWT. Kepala juga ikut bergerak perlahan sesuai dengan alur dhikir, dari bawah ke atas (la), ke dada kanan (ilaha) dan akhirnya "dipukulkan" dengan keras ke jantung atau dada kiri (illa Allah) .46

Amalan dhikir nafi ithbat (la ilaha illallah) ini dilakukan oleh murid terutama setelah shalat fardhu, sedangkan dhikir ism dzat (Allah) dilaksanakan setiap saat. Dalam hal ini Ibn 'Athaillah menyatakan, bahwa: Jangan engkau tinggalkan dhikir dikarenakan engkau tidak merasakan kehadiran Allah SWT dalam dhikir tersebut. Sebab kelalaianmu terhadapNya dengan tidak berdhikir kepada-Nya itu lebih berbahaya daripada kelalaianmu kepada-Nya dengan adanya dhikir kepada-Nya. ${ }^{47}$ Dhikir adalah sebaik-baik jalan menuju Allah SWT, jadi tidak boleh ditinggalkan walaupun sedang tidak konsentrasi penuh. Sebaiknya memang dengan menghadirkan Allah SWT dalam hati, sehingga mampu mencapai dhikir yang dapat melupakan segalanya selain Allah SWT.

Dalam hal ini Ibn 'Athaillah menganjurkan kepada seseorang yang ingin mencapai ma'rifat agar menempuh tujuh langkah: senantiasa bersungguh-sungguh (al-juhd), merendahkan diri kepada Allah SWT (al-tadharru),

46 Martin Van Bruinessen, Kitab Kuning, Pesantren dan Tarekat (Bandung: Mizan, 1995), 216.

47 Ibn 'Athaillah, Al-Hikam, terj. Salim Bahraish dengan judul terjemah al-Hikam, Pendekatan Abdi pada Khaliqnya (Surabaya: Balai Buku, 1984), 55. 
membakar hawa nafsu (ihtiraq al-nafs), kembali dan taubat kepada Allah SWT (al-inabah), senantiasa sabar (al-shabr), selalu bersyukur kepada Allah SWT (al-Syukr) dan senantiasa rela atas taqdir dan ketentuan Allah SWT (alridha). ${ }^{48}$

Memang untuk mendaki derajat yang tinggi harus dengan upaya yang sungguh-sunggh dan harus melatih diri untuk dapat mengalahkan segala rintangan yang menghalangi pendakian tersebut. Pada saatnya nanti Allah SWT akan menolong dengan memberikan petunjuk-Nya. Sebagaimana Firman-Nya:

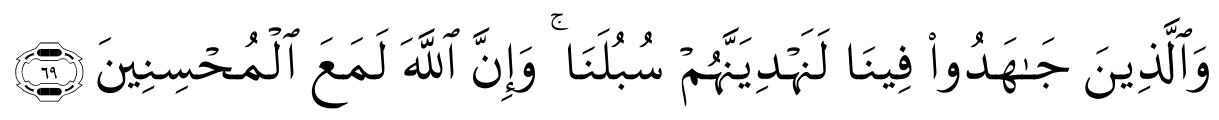

"Dan orang-orang yang berjihad untuk (mencari keridhaan) Kami, benar- benar akan Kami tunjukkan kepada mereka jalan-jalan kami. dan Sesungguhnya Allah benar-benar beserta orang-orang yang berbuat baik." 49

\section{Shalawat kepada Nabi Muhammad SAW}

Membaca shalawat kepada Nabi Muhammad SAW dengan maksud untuk memohonkan rahmat dan karunia bagi Nabi SAW agar yang membaca juga mendapat balasan limpahan rahmat dari Allah SWT. Ibn 'Athaillah menyarankan kepada para murid untuk selalu membaca shalawat Nabi siang malam terutama setelah shalat fardhu. Bacaan shalawat Nabi SAW dengan menggunakan sayyidina, karena di dalamnya terdapat rahasia yang luhur sebagai

48 Ibn 'Athaillah, Al-Hikam, 55.

49 Al-Qur'an, 29 (al-Ankabut): 69 
ungkapan penghormatan khusus dan derajat cinta yang tinggi kepada Nabi Muhammad SAW. ${ }^{50}$

Membaca shalawat Nabi SAW merupakan ungkapan cinta (mahabbah) dari seorang pecinta kepada diri Nabi Muhammad SAW. Barang siapa mencintai seseorang maka ia akan selalu mengingatnya dan mendo'akannya agar selalu dalam rahmat-Nya. Dan tentu orang yang dicintai akan membalas segala kebaikan dan do'anya dengan penuh kasih sayang dan cinta. Demikian pula apabila seorang murid telah terjalin cinta karena Allah SWT (mahabbah fi Allah) dengan Nabi Muhammad SAW, maka tentu Allah SWT akan memberikan rahmat dan karunia kepada orang tersebut. Barang siapa mencintai Nabi Muahammad SAW berarti dia mencintai Allah SWT dan barang siapa yang dicintai oleh Allah SWT berarti dia dekat dengan-Nya (al-qurb). Allah SWT juga memerintahkan kepada manusia agar membaca shalawat kepada Nabi Muhammad SAW, dengan firman-Nya:

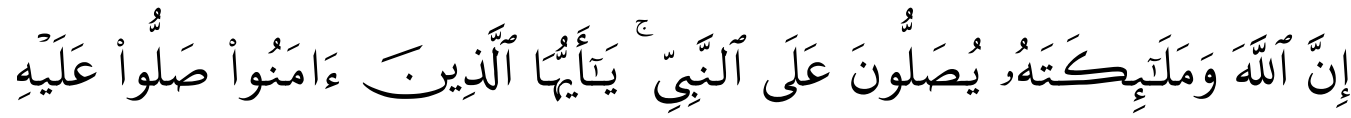

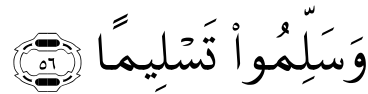

"Sesungguhnya Allah dan malaikat-malaikat-Nya bershalawat untuk Nabi. Hai orang-orang yang beriman, bershalawatlah kamu untuk Nabi dan ucapkanlah salam penghormatan kepadanya." 51

Dalam tafsir al-Qur'an bershalawat artinya: kalau dari Allah berarti memberi rahmat; dari Malaikat berarti memintakan ampunan dan kalau dari orang-orang mukmin

50 Ibn 'Athaillah, Miftah al-Faidh wa Misbah al-Arwah (Mesir: Maktabah Muhammad Ali al-Shabi wa Awladih, tt.), 38.

${ }^{51}$ Al-Qur'an, 33 (al-Ahzab): 56.

Jurnal Pendidikan Agama Islam

Volume 02 Nomor 01 Mei 2014

Hal $76-87$ 
berarti berdoa supaya diberi rahmat seperti dengan perkataan: Allahumma shalli 'ala Muhammad, artinya: Wahai Allah limpahkanlah rahmat yang sempurna kepada Nabi Muhammad SAW. Bacaan salam dengan mengucapkan perkataan seperti: Assalamu'alaika ayyuhan Nabiy artinya: semoga keselamatan tercurah kepadamu wahai Nabi. ${ }^{52}$

\section{Hizib}

Hizib menurut bahasa berarti tentara atau pasukan. Sedangkan istilah hizib digunakan sebagai sebutan suatu do'a yang cukup panjang dengan lirik dan bahasa yang indah yang disusun oleh ulama' besar. ${ }^{53}$ Hizib adalah kumpulan do'a khusus yang sudah populer di kalangan masyarakat Islam khususnya di pesantren dan thariqah. Hizib ini biasanya merupakan do'a andalan seorang shaykh yang diberikan kepada muridnya secara ijazah yang jelas. Do'a ini diyakini oleh kebanyakan masyarakat Islam atau kaum santri sebagai amalan yang memiliki daya spiritual yang besar. ${ }^{54}$

Daya spiritual hizib itu bukan dari jin tetapi dari Allah SWT. Apabila terjadi kasus seseorang yang mengamalkan hizib ini dan ternyata jin turut campur, maka yang perlu diluruskan adalah niat seseorang mengamalkan hizib tersebut. Amal sebaik apapun jika niat di dalam hatinya jahat, maka niat jahatnya itulah yang akan menjadi kenyataan dan hasilnya akan menuai sesuai dengan niatnya yang tidak ikhlas karena Allah SWT. Oleh karena itu seseorang yang akan mengamalkan hizib yang paling

53 Lihat Abi 'Abdillah, Dalail.

54 Masyhuri, Fenomena Alam jin, Pengalaman Spiritual dengan Jin (Solo: CV. Aneka, 1996), 7. 
penting adalah menata dan meluruskan niat dalam hati semata-mata hanya karena Allah SWT.

Shaykh Abu Hasan 'Ali al-Shadhili telah berwasiat kepada para pengikutnya dalam hal hizib ini sebagai berikut: "semua murid yang mengikuti thariqah Shadhiliyah supaya mengamalkan hizib al-bahr karena di dalamnya terdapat nama-nama Allah yang mulia, yang besar berkahnya"55 Dengan membaca asma' al-husna berarti seseorang berdhikir dan mengingat Allah SWT dengan 99 nama yang setiap nama memiliki pengaruh spiritual yang besar. Dan pengaruh spiritual itu akan didapat oleh siapapun yang mengamalkan, dengan syarat menerima ijazah dari guru yang berwenang.

Adapun hizib-hizib tersebut, antara lain adalah hizb alNasr, hizb al-kafi atau hizb al-autad, hizb al-bahr, hizb albarr, hizb al-mubarak, hizb al-asfa', hizb al-birhatiyah, hizb al-fath, hizb al-ayat, hizb al-Shaykh Abi al-Hasan, hizb alsaghir, hizb al-kabir .56 Hizib-hizib tersebut tidak boleh diamalkan oleh setiap orang, kecuali sudah mendapat izin atau ijazah dari murshid atau seorang murid yang ditunjuk oleh murshid untuk mengijazahkannya.

\section{5. 'Ataqah atau Fida'}

Ataqah menurut bahasa adalah pemerdekaan dan fida' adalah penebusan. Yang dimaksud 'ataqah adalah memerdekakan diri dari siksa api neraka dan fida' adalah menebus dosa, membersihkan jiwa dari kotoran-kotoran dan penyakit-penyakit jiwa dan untuk menebus dosa agar

\footnotetext{
55 'Abd al-Khaliq al-Hilali, Durrah al-Salikin fi Dhikr al-Silsilah al-Thariqah alSyadhiliyah al-Mu'tabarah (tp.: tt., 1980), 2.

56“Abd al-Halim Mahmud, al-Madrasah al-Syadhaliyyah (Mesir: Dar al-Kutub alHadithah, 1968), 175-201. 
dapat masuk surga ${ }^{57}$. Atau penebus pengaruh jiwa yang tidak baik (untuk mematikan nafsu). ${ }^{58}$

Bentuk dan cara 'ataqah ini adalah berupa seperangkat amalan tertentu yang dilaksanakan dengan sungguh-sungguh (mujahadah) yaitu membaca surat ikhlas seratus ribu kali atau membaca kalimat tahlil la ilaha illa Allah sebanyak tujuh puluh ribu kali, dalam rangka penebusan dosa dan penebusan nafsu amarah dan nafsunafsu yang lain. Dalam pelaksanaan 'ataqah atau fida' ini bisa dicicil semampunya. ${ }^{59}$ Setiap kali selesai membaca diakhiri dengan do'a fida' dan dicatat jumlahnya agar diketahui batas akhir membacanya. Kalau sudah selesai membaca 'ataqah/fida' untuk diri sendiri, boleh membacakannya untuk ahli quburnya yang sudah meninggal dunia. Sebagaimana firman Allah SWT:

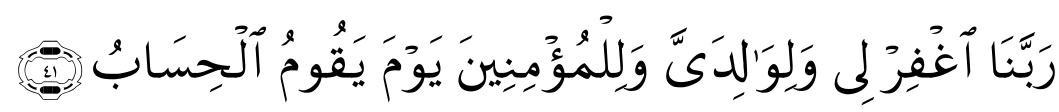

"Ya Tuhan Kami, beri ampunlah aku dan kedua ibu bapaku dan sekalian orang-orang mukmin pada hari terjadinya hisab (hari kiamat)."60

\section{Istighatsah}

Istighatsah maksudnya adalah meminta pertolongan kepada Allah SWT dalam segala hal, termasuk agar mencapai kemenangan dalam menghadapi musuh-musuh-Nya. Esensi istighatsah adalah berdoa, tetapi biasanya dilakukan dengan berdoa bersama membaca serangkaian bacaan dhikir yang

\footnotetext{
57 Zamraji Saeraji, al-Tadhkirat al-Nafi'at fi Silsilah al-Thariqah al-Qadiriyyah wa Naqshabandiyyah, Jilid II (Pare: tp., 1986), 4

58 Isma'il Ibnu M. Sa'id al-Qadiri, al-Fuyudhat al-Rabbaniyyah fi al-Ma'athir wa al-Aurad al-Qadiriyah (Kairo: Mash-had al-Husaini, tt.), 15.

${ }^{59}$ Zamraji, al-Tadhkirat, 4.

60 Al-Qur'an, 14 (Ibrahim): 41.
} 
terssusun dari ayat-ayat al-Qur'an, istighfar, shalawat Nabi, asma' al-husna, tahmid, tahlil, tasbih, takbir dan doa.

Istighatsah, pernah dicontohkan Rasulullah SAW ketika terjadi perang badar, karena melihat tentara kaum muslimin hanya berjumlah 313 orang, sedangkan kaum kafir berjumlah 1000 orang, maka Allah menurunkan bala bantuan sejumlah 1000 malaikat. Sebagaimana firman-Nya:
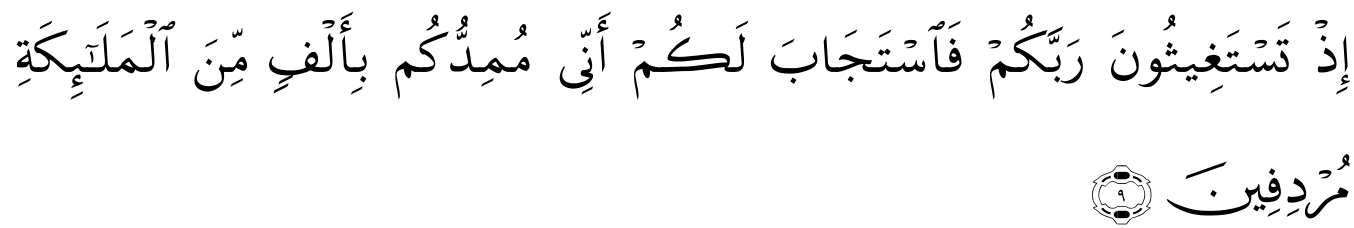

"Ingatlah ketika kamu sekalian mohon pertolongan kepada Tuhanmu, lalu diperkenankan-Nya bagimu: "Sesungguhnya aku akan mendatangkan bala bantuan kepada kamu dengan seribu Malaikat yang datang berturut-turut."61

\section{Muraqabah}

Kontemplasi atau muraqabah adalah seseorang duduk mengheningkan cipta dengan penuh kesungguhan hati, dengan penghayatan seolah-olah berhadapan dengan Allah SWT, meyakinkan hati bahwa Allah SWT senantiasa mengawasi dan memperhatikan segala perbuatannya. ${ }^{62}$ Dengan latihan muraqabah ini seseorang akan memiliki nilai ihsan yang lebih unggul, dan akan dapat merasakan kehadiran Allah kapan saja dan di mana saja ia berada.

Muraqabah memiliki perbedaan dengan dhikir terutama pada objek pemusatan kesadaran (konsentrasinya). Kalau dhikir memiliki objek perhatian pada simbul yang berupa kata atau kalimat, sedangkan muraqabah

\footnotetext{
${ }^{61}$ Al-Qur'an, 8 (al-Anfal): 9.

62 Muhammad Shadiq 'Urjun, al-Tashawwuf fi al-Islam Manabi'uh wa Athwaruh (Kairo: Mathba'ah al-Kulliyah al-Azhariyah, 1967), 39.
} 
menjaga kesadaran atas makna, sifat qudrat dan iradah Allah SWT. Demikian juga media yang digunakan memiliki perbedaan, dzikir menggunakan lidah, sedangkan muraqabah menggunakan kesadaran dan imajinasi. ${ }^{63}$

\section{Puasa}

Puasa merupakan salah satu amalan dalam pendidikan tasawuf, yaitu beberapa amalan puasa sunnah, antara lain:

a. Puasa hari Senin dan Kamis.

b. Puasa hari 'arafah, yaitu puasa pada tanggal 9 bulan Dhul Hijjah.

c. Puasa hari 'ashura', yaitu puasa tanggal sepuluh bulan Muharram.

Sebagaimana sabda Nabi Muhammad SAW. :

ان رسول الله صل الله عليه وسلم سئل عن صوم يوم عرفة فقال " يكفر السنة

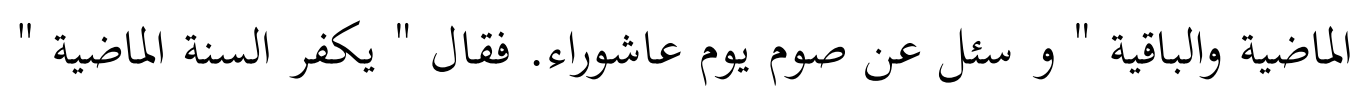
و سئل عن صوم يوم الاثنين فقال : ذالك يوم ولدت فيه وبعثت فيه وانزل علي فيه.

"Sesungguhnya Rasulullah SAW ditanya tentang puasa hari 'Arafah, dia bersabda: Dapat menghapus dosa setahun yang lalu dan setahun yang akan datang. Dan ditanya tentang puasa hari 'Ashura', dia bersabda: dapat menghapus dosa setahun yang lalu. Dan ditanya tentang puasa hari Senin, dia bersabda: hari itu adalah hari aku dilahirkan, dan aku diutus menjadi Rasul dan hari diturunkan wahyu kepadaku."64

63 Kharisudin Aqib, Tarekat Qadiriyah \& Naqsyabandiyah Suryalaya: Studi tentang Tazkiyatun Nafs sebagai Metode Penyadaran Diri, Disertasi (Jakarta: IAIN Syarif Hidayatullah,2001), 117.

64 Imam Muslim, Shahih Muslim, 346. 
d. Puasa enam hari di bulan Syawwal.

Berdasarkan sabda Nabi Muhammad SAW.

من صام رمضان ثم اتبعه ستا من شوال كان كصيام الدهر . رواه مسلم.

"Barang siapa puasa Ramadhan kemudian diiringi dengan puasa enam hari pada bulan Syawal, maka seperti puasa setahun."65

e. Puasa tiga hari setiap bulan pada tanggal tiga belas, empat belas dan lima belas hijriyah. Sebagaimana sabda Nabi Muhammad SAW:

امرنا رسول الله صل الله عليه وسلم ان نصوم من الشهر ثلاثة ايام : ثلاث

عشرة واربع عشرة وخمس عشرة. رواه النسائ والترمذى وصححه ابن حبان.

"Rasulullah SAW memerintah kami agar berpuasa tiga hari dalam sebulan, yaitu tigabelas, empatbelas dan limabelas (bulan hijriyah)." "66

f. Puasa di bulan Sha'ban.

Berdasarkan sabda nabi Muhammad SAW:

كان رسول الله صل الله عليه وسلم يصوم حتى نقول لايفطر ويفطر حتى

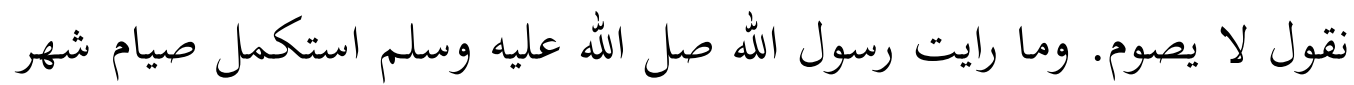
قط الا رمضان. وما رايته في شهر اكثر منه صياما في شعبان. متفق عليه

"Adalah Rasul SAW berpuasa, hingga kami mengira tidak akan berbuka, dan beliau tidak berpuasa sehingga kami mengira tidak akaan berpuasa, daan aku tidak pernah melihat Rasul SAW berpuasa sebulan penuh, kecuali pada bulan ramadhan, dan aku tidak melihat beliau berpuasa

65 Imam Muslim, Shahih Muslim, 348.

66 Imam Muslim, Shahih Muslim, 347. 
dalam sebulan yang lebih banyak dari puasanya di bulan Sya'ban."67

\section{Signifikansi Maqamat dan Amalan-amalan pada Pendidikan Tasawuf dalam Perubahan Perilaku Manusia.}

Maqamat atau tahapan-tahapan pada pendidikan tasawuf yang terdiri dari taubat, istiqamah, zuhud, qana'ah dan raja' dilaksanakan di bawah bimbingan seorang guru/murshid dalam kehidupan sehari hari secara terus menerus, menjadikan murid diampuni dosanya oleh Allah SWT karena senantiasa bertaubat, terbiasa hidup disiplin, teguh pendidirian, rajin beribadah karena menerapkan istiqamah, mengutamakan Allah SWT dan kehidupan akhirat karena melaksanakan zuhud, menerima dengan senang hati segala pemberian Allah SWT kepadanya dengan qana'ah dan senantiasa berharap atas rahmat Allah SWT dengan menerapkan raja'.

Amalan-amalan pada pendidikan tasawuf dengan maqamat ini saling berkaitan satu dengan lainnya. Hal yang berkaitan dengan taubat adalah istighfar atau permohonan ampun kepada Allah SWT dan 'ataqah / fida' ya'ni pemerdakaan dan penebusan diri dari dosa. Hal yang berhubungan dengan istiqamah adalah dhikir, shalawat Nabi, hizib dan istighatsah karena pelaksanaannya setelah shalat fardhu dan shalat malam. Hal ini merupakan pembiasaan yang kuat. Sesuatu yang sudah terbiasa maka akan sulit atau berat untuk meninggalkannya. Muraqabah dan puasa merupakan amalan pendekatan diri kepada Allah SWT yang dapat melahirkan qana'ah, zuhud dan raja'.

Tahapan-tahapan atau maqamat dan amalan-amalan pada pendidikan tasawuf yang diajarkan, dibimbing, dibina,

67 Imam Bukhari, Shahih Bukhari, 414. 
dan dilatih oleh seorang guru/murshid dengan disiplin, mampu merubah mindset seseorang dari kecenderungan pada dunia menuju kecenderungan pada akhirat, dari kecenderungan pada penurutan hawa nafsu menuju kecenderungan pada ketaatan kepada Allah SWT.

Hal ini terjadi karena adanya motivasi atau dorongan. Motivasi itu sendiri menurut Glaiman adalah pemasok daya (energizer) untuk bertingkah laku secara terarah. ${ }^{68}$ Motivasi berfungsi sebagai pendorong perbuatan, sebagai penggerak perbuatan, sebagai pengarah perbuatan dan sebagai penguatan bersemayamnya segala informasi dalam memori seorang.

Adanya motivasi yang ditumbuhkan, ditanamkan dan dikembangkan oleh guru/murshid terhadap muridnya dalam proses pendidikan tasawuf ini merupakan pendorong, penggerak, pengarah dan penguatan terhadap penguasaan dan semangat pengamalan ajaran-ajaran tasawuf dalam kehidupan seorang murid.

Maqamat dan amalan-amalan pada pendidikan tasawuf yang disertai dengan motivasi yang kuat, dapat melahirkan tingkah laku manusia yang cenderung baik dan terpuji. Menurut Imam Ghazali, tingkah laku terpuji itu disebabkan atas tiga faktor pendorong, yaitu:

1. Pendorong ke arah kebutuhan akan penghargaan yang berupa perolehan pahala dan surga dari Allah SWT.

2. Pendorong ke arah kebutuhan akan sanjungan dari Allah SWT.

3. Pendorong ke arah kebutuhan akan keridhaan Allah SWT dan kedekatan dengan-Nya. ${ }^{69}$

\footnotetext{
68 Muhibbin Syah, Psikologi Belajar (Jakarta: P.T. Gravindo Persada, 2003), 151.

${ }^{69}$ Imam Ghazali, Mizan al-'Amal (Beirut: Dar al-Kutub al-Ilmiyah, 1989), 93. 


\section{E. Penutup}

Dari uraian diatas dapat simpulkan bahwa maqamat berupa taubat, istiqamah, zuhud, qana'ah, raja' dan amalanamalan pada pendidikan tasawuf berupa istighfar, dhikir, shalawat Nabi, hizib, 'ataqah, istighatsah, muraqabah dan puasa yang dibimbing, diajar, dibina dan dilatih oleh guru/ murshid dapat merubah mindset seseorang. Melalui motivasi yang ditumbuhkan, ditanamkan dan dikembangkan oleh guru/ murshid kepada murid serta adanya kebutuhan-kebutuhan akan pahala, surga, sanjungan, keridhaan dan kedekatan dengan Allah SWT, merupakan pendorong dan penggerak untuk bertingkah laku sebagaimana yang diajarkan oleh guru/ murshid; antara lain mengutamakan kepentingan akhirat, memerangi hawa nafsu, taat pada Allah SWT.

\section{DAFTAR PUSTAKA}

\section{Al-Qur'an al-Karim}

Abu al-Qasim 'Abd al- Karim al Qushairy, Risalah al-Qushairiyah (Kairo: Dar al-Khair, tt).

'Abd al-Khaliq al-Hilali, Durrah al-Salikin fi Dhikr al-Silsilah alThariqah al-Syadhiliyah al-Mu'tabarah (tp.: tt., 1980).

'Abd al-Halim Mahmud, al-Madrasah al-Syadhaliyyah (Mesir: Dar al-Kutub al-Hadithah, 1968).

Al-Jami' al-Shaghir, Juz I.

'Abd al-Wahab al-Sha'rani, Minah al-Saniyyah (Surabaya: alHidayah, tt.).

'Abdul Qadir 'Isa, Hakikat Tasawuf ( Jakarta: Qisthi Press, 2005). Al-Sarraj, al-Luma' fi al-Tashawwuf (Kairo: Dar al-Kutub alHadithah,1960). 
'Ali Hasan al-'Aridh, Bahjat al-Nufus li Ibn 'Athaillah (Kairo: M. Taufiq Uwaudhat, 1969).

Abu 'Abbas Ahmad Zaruq al-Fasi, Qawa'id al-Tashawwuf.

Abi 'Abdillah, Dalail.

Imam Bukhari, Shahih Bukhari, Juz II (Beirut: Dar al-Kutub al'Ilmiyah, 2005).

Imam Bukhari, Shahih Bukhari, Juz IV ( Beirut: Dar al-Kutub al 'Ilmiyah, 2005).

Imam Muslim, Shahih Muslim, Juz II (Mesir: Isa al-Babi al-Halibi, tt.).

Imam Turmudzi, Sunan Turmudzi (Beirut: Dar al-Fikr,1980).

Imam Tirmidzi, Sunan al-Tirmidzi (Beirut: Dar Ibnu Hazm, 2002).

Ibn 'Athaillah, Al-Hikam, terj. Salim Bahraish dengan judul terjemah al-Hikam, Pendekatan Abdi pada Khaliqnya (Surabaya: Balai Buku, 1984).

Ibn 'Athaillah, Miftah al-Faidh wa Misbah al-Arwah (Mesir: Maktabah Muhammad Ali al-Shabi wa Awladih, tt.).

Ibn 'Athaillah, Miftah al-Falah wa Mishbah al-Arwah (Mesir: Maktabah 'Ali Shabih wa Awladih, tt.).

Imam Ibnu Majah, Sunan Ibnu Majah, Juz I ( Beirut: Dar al-Fakr, 2004).

Isma'il Ibnu M. Sa'id al-Qadiri, al-Fuyudhat al-Rabbaniyyah fi alMa'athir wa al-Aurad al-Qadiriyah (Kairo: Mash-had alHusaini, tt.).

Imam Ghazali, Mizan al-'Amal (Beirut: Dar al-Kutub al-Ilmiyah, 1989).

Kharisudin Aqib, Tarekat Qadiriyah \& Naqsyabandiyah Suryalaya: Studi tentang Tazkiyatun Nafs sebagai Metode Penyadaran Diri, Disertasi (Jakarta: IAIN Syarif Hidayatullah,2001). Muhammad Shadiq 'Urjun, al-Tashawwuf fi al-Islam Manabi'uh wa Athwaruh (Kairo: Mathba'ah al-Kulliyah al-Azhariyah, 1967). 
Martin Van Bruinessen, Kitab Kuning, Pesantren dan Tarekat (Bandung: Mizan, 1995).

Muhammad Idris, Kamus Idris al-Marbawi, Jilid II.

Masyhuri, Fenomena Alam jin, Pengalaman Spiritual dengan Jin (Solo: CV. Aneka, 1996).

Muhibbin Syah, Psikologi Belajar (Jakarta: P.T. Gravindo Persada, 2003).

Shaykh Mas'ud Thaha, Murshid Thariqah Shahaliyah dan Pengasuh Pondok Pesantren Nurul Huda Magelang, Ceramah, Magelang, 16 November 1999.

Sayyid Ahmad Hashimi, Mukhtar al-Hadith al-Nabawiyyah (Kairo: Shirkah Nur Asia, tt).

Zamraji Saeraji, al-Tadhkirat al-Nafi'at fi Silsilah al-Thariqah alQadiriyyah wa Naqshabandiyyah, Jilid II (Pare: tp., 1986). 